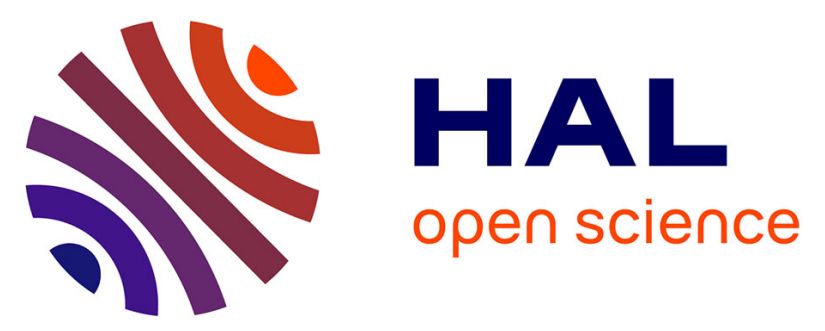

\title{
Tracking the early dispersion of contaminated sediment along rivers draining the Fukushima radioactive pollution plume
}

\author{
Caroline Chartin, O. Evrard, Yuichi Onda, Jérémy Patin, Irène Lefevre, \\ Catherine Ottle, Sophie Ayrault, Hugo Lepage, Philippe Bonté
}

\section{To cite this version:}

Caroline Chartin, O. Evrard, Yuichi Onda, Jérémy Patin, Irène Lefevre, et al.. Tracking the early dispersion of contaminated sediment along rivers draining the Fukushima radioactive pollution plume. Anthropocene, 2013, 1, pp.23-34. 10.1016/j.ancene.2013.07.001 • cea-02614734

\section{HAL Id: cea-02614734 https://hal-cea.archives-ouvertes.fr/cea-02614734}

Submitted on 21 May 2020

HAL is a multi-disciplinary open access archive for the deposit and dissemination of scientific research documents, whether they are published or not. The documents may come from teaching and research institutions in France or abroad, or from public or private research centers.
L'archive ouverte pluridisciplinaire HAL, est destinée au dépôt et à la diffusion de documents scientifiques de niveau recherche, publiés ou non, émanant des établissements d'enseignement et de recherche français ou étrangers, des laboratoires publics ou privés. 


\section{Tracking the early dispersion of contaminated}

\section{sediment along rivers draining the Fukushima}

\section{radioactive pollution plume}

Caroline Chartin ${ }^{a}$, Olivier Evrard ${ }^{a,{ }^{*}}$, Yuichi Onda ${ }^{b, *}$, Jeremy Patin $^{b}$, Irène Lefèvre ${ }^{a}$, Catherine Ottle $^{a}$, Sophie Ayrault ${ }^{a}$, Hugo Lepage ${ }^{a}$, Philippe Bonté ${ }^{a}$

\section{AUTHOR ADDRESSES}

${ }^{a}$ Laboratoire des Sciences du Climat et de l'Environnement (LSCE/IPSL), Unité Mixte de Recherche 8212 (CEA, CNRS, UVSQ), 91198, Gif-sur-Yvette Cedex, France

${ }^{\mathrm{b}}$ Center for Research in Isotopes and Environmental Dynamics (CRIED), University of Tsukuba, 1-1-1 Tennodai, Tsukuba, Ibaraki 305-8572, Japan

${ }^{*}$ Corresponding authors.

E-mail addresses: olivier.evrard@1sce.ipsl.fr (O. Evrard); onda@geoenv.tsukuba.ac.jp (Y. Onda)

Keywords: erosion; sediment; river catchments; contamination; transfer 


\section{ABSTRACT}

7 Soil erosion and subsequent sediment transport in rivers play a major role in the global

8 biogeochemical cycles and on the dispersion of contaminants within the natural environment. As

9 other particle-borne pollutants, fallout radionuclides emitted after the Fukushima Dai-ichi

10 Nuclear Power Plant (FDNPP) accident are strongly sorbed by fine particles, and they are

11 therefore likely to be redistributed by hydro-sedimentary processes across catchments. Although

12 regrettable, the Fukushima catastrophe and the associated massive radionuclide release provide a

13 unique opportunity to track the dispersion of sediment in catchments exposed to typhoons and to

14 better understand the anthropogenic impacts on particle-borne transfers within the natural

15 environment. Fieldwork around FDNPP and subsequent lab work on Fukushima samples

16 required the compliance with very demanding radioprotection and security rules. Here, we

17 collected exposed riverbed sediment $(n=162)$ along rivers and in reservoirs draining the

18 catchments contaminated by the main radioactive pollution plume that extends across Fukushima

19 Prefecture in November 2011, April 2012 and November 2012. We measured their gamma-

20 emitting radionuclide activities and compared them to the documented surveys in nearby soils.

21 We show that the ${ }^{110 \mathrm{~m}} \mathrm{Ag}:{ }^{137} \mathrm{Cs}$ ratio provided a tracer of the dispersion of contaminated sediment

22 in one specific catchment draining the most contaminated area. Our results demonstrate that the

23 system was very reactive to the succession of summer typhoons and spring snowmelt. We

24 identified a partial export of contaminated sediment from inland mountain ranges - exposed

25 initially to the highest radionuclide fallout - to the coastal plains as soon as in November 2011,

26 after a series of violent typhoons. This export was amplified by the spring snowmelt, and

27 remaining contaminated material temporarily stored in the river channel was flushed by the

28 typhoons that occurred during summer in 2012. This catchment behaviour characterized by the 
29 high transmissivity of paddy fields strongly connected to the river network in upland mountain 30 ranges and the potential storage in the coastal plains that are successively filled with 31 contaminated sediment and then flushed was illustrated by the calculation of an index of hydro32 sedimentary connectivity and the construction of river longitudinal profiles. We thereby suggest 33 that coastal rivers have become a perennial supply of contaminated sediment to the Pacific 34 Ocean. Our findings show that Fukushima accident produced original tracers to monitor particle35 borne transfers across the affected area shortly after the catastrophe. Furthermore, we outlined 36 that this accident generated a distinct geological record that will be useful for sediment dating 37 behind reservoirs in Japan during the next decades.

\section{INTRODUCTION}

40 As a consequence of the magnitude 9.0 earthquake and the subsequent tsunami that occurred on 4111 March 2011 (Simons et al., 2011), the Fukushima Dai-ichi Nuclear Power Plant (FDNPP) 42 underwent a series of serious damages (Burns et al., 2012). After failure of the cooling systems, 43 several hydrogen explosions affected three of the six nuclear reactors of the power plant on 44 March 12, 14 and 15, and affected a fourth reactor which had already been stopped (Achim et al., 45 2012). Significant quantities of radionuclides were released into the environment between 12 and 4631 March (Morino et al., 2013). Radioactive substance quantities released by the FDNPP 47 accident were estimated to reach $11-40 \%(190-700 \mathrm{PBq})$ of the total amount of ${ }^{131}$ I and $14-62 \%$ 48 (12- 53.1 PBq) of the total ${ }^{137}$ Cs emitted by Chernobyl accident (Chino et al., 2011; Nuclear 49 Safety Commission of Japan, 2011; IRSN, 2012; Stohl et al., 2012; Winiarek et al., 2012). 50 Despite the bulk of radionuclides $(\sim 80 \%)$ were transported offshore and out over the Pacific 51 Ocean (Buesseler et al., 2011; Masson et al., 2011), significant wet and dry deposits of those 
52 radionuclides occurred predominantly in Fukushima Prefecture on 15-16 March, leading to a 53 strong contamination of soils (Yasunari et al., 2011; Kinoshita et al., 2011). In particular, 6.4

$54 \mathrm{PBq}$ of ${ }^{137} \mathrm{Cs}(\sim 20 \%$ of the total emissions $)$ were modeled to have deposited on Japanese soils 55 (Stohl et al., 2012) over a distance of $70 \mathrm{~km}$ to the northwest of FDNPP (Fig. 1a). Soils 56 characterized by a ${ }^{137} \mathrm{Cs}$ contamination exceeding $100 \mathrm{kBq} \cdot \mathrm{m}^{-2}$ cover ca. $3000 \mathrm{~km}^{2}$ (MEXT, 57 2011).

When reaching such high levels, radioactive contamination constitutes a real threat for 59 the local populations. Resulting radiations lead to an external exposure threat that depends on the 60 spatial distribution of radionuclides and the time of exposition (Endo et al., 2012; Garnier61 Laplace et al., 2011). This threat, associated with the possibility of transfer of contamination to 62 plants, animals and direct ingestion of contaminated particles, will affect human activities such 63 as agriculture, forest exploitation and fishing for long periods of time, depending on the half-life 64 of the radionuclides (e.g., 2 yrs for ${ }^{134} \mathrm{Cs} ; 30$ yrs for ${ }^{137} \mathrm{Cs}$ ). Those latter substances are strongly 65 sorbed by soil particles (and especially by their clay, silt and organic matter fractions) and may 66 therefore be delivered to rivers by runoff and erosion processes triggered on hillslopes (Motha et 67 al., 2002; Tamura, 1964; Whitehead, 1978). This sediment may then further convey 68 contaminants in rivers, and its transfer can lead to the dispersion of radioactive contamination 69 across larger areas over time (Rogowski and Tamura, 1965, Simpson et al., 1976). To our 70 knowledge, those transfers following the FDNPP releases have only been investigated at the 71 scale of individual fields (e.g. Koarashi et al., 2012) or in very small catchments of northeastern 72 Japan (Ueda et al., 2013). Still, assessing as soon as possible the spatial and temporal variations 73 of radioactive contaminant dispersion has become one of the major concerns for the protection of 74 natural ecosystems and human populations living in this region. 
75 In addition to problems associated with the high radioactive contamination which 76 justifies its urgent monitoring at the regional scale, this event, although regrettable, also 77 constitutes a unique scientific opportunity to track in an original way particle-borne transfers that 78 play a major role in global biogeochemical cycles (Van Oost et al., 2007) and in the transfer of 79 contaminants within the natural environment (Meybeck, 2003). Conducting this type of study is 80 particularly worthwhile in Japanese mountainous river systems exposed to both summer 81 typhoons and spring snowmelt, where we can expect that those transfers are rapid, massive and 82 episodic (Mouri et al., 2011).

83 During this study, fieldwork required being continuously adapted to the evolution of the 84 delineation of restricted areas around FDNPP, and laboratory experiments on Fukushima 85 samples necessitated the compliance with specific radioprotection rules (i.e., procedures for 86 sample preparation, analysis and storage). In addition, the earthquake and the subsequent 87 tsunami led to the destruction of river gauging stations in the coastal plains, and background data 88 (discharge and suspended sediment concentrations) were unavailable during the study period. 89 Monitoring stations have only become operational again from December 2012 onwards.

90 In this post-accidental context, this paper aims to provide alternative methods to estimate 91 the early dispersion of contaminated sediment during the 20 months that followed the nuclear 92 accident in those mountainous catchments exposed to a succession of erosive rainfall, snowfall 93 and snowmelt events. It will also investigate, based on the radioisotopes identified, whether the 94 accident produced geological records, i.e. characteristic properties in sediment deposit layers, 95 that may be used in the future for sediment tracing and dating. 

113 were drawn from data provided by MEXT for these 2200 investigated locations. We 114 hypothesised that those radionuclides were concentrated in the soil upper $2 \mathrm{~cm}$ layer, and that 115 soils had a mean bulk density of $1.15 \mathrm{~g} . \mathrm{cm}^{-3}$ based on data collected in the area (Kato et al., 116 2011; Matsunaga et al., 2013). Within this set of 2200 soil samples, ${ }^{110 \mathrm{~m}} \mathrm{Ag}$ activities were only 117 reported for a selection of 345 samples that were counted long enough to detect this radioisotope 118 (Fig. 3, 4). All activities were decay corrected to 14 June 2011. A map of total radiocaesium 119 activities was interpolated across the entire study area by performing ordinary kriging to

\subsection{Study site and mapping of initial soil contamination}

The objective of the study that covered the period from November 2011 to November 2012 was to document the type and the magnitude of radioactive contamination found in sediment collected along rivers draining the main radioactive pollution plume that extends over 20 to 50 $\mathrm{km}$ to the northwest of FDNPP in Fukushima Prefecture (Fig. 1a). For this purpose, we measured their gamma-emitting radionuclide activities and compared them to the documented surveys in nearby soils. In association with the U.S. Department of Energy (DOE), the Japanese Ministry of Education, Culture, Sports, Science and Technology (MEXT) performed a series of detailed airborne surveys of air dose rates 1-m above soils and of radioactive substance deposition (gamma-emitting) in the ground surface shortly after the nuclear accident (from 6 to 29 April 2011) in Fukushima Prefecture (MEXT and DOE, 2011). The MEXT sampled and analysed gamma-emitting radionuclides in the upper 5-cm layer of soil collected from 2200 sites located within a radius of approximately $100 \mathrm{~km}$ around FDNPP during June and July 2011 to validate and enlarge the use of these airborne surveys (MEXT, 2011a). Background maps of point-based radionuclide inventories in soils $\left({ }^{134} \mathrm{Cs}+{ }^{137} \mathrm{Cs},{ }^{110 \mathrm{~m}} \mathrm{Ag}\right)$ designed in this study (Fig. 1a, 2, 3, 4, 7) activities was interpolated across the entire study area by performing ordinary kriging to 
120 appreciate regional fallout patterns in soils (Fig. 1a, 2, 7; Chilès and Delfiner, 1988; Goovaerts, 121 1997). A cross validation was then applied to the original data to corroborate the variogram 122 model. The mean error (R) was defined as follows (Eq. 1):

$123 R=\frac{1}{n} \sum_{i=1}^{n}\left[z *\left(x_{i}\right)-z\left(x_{i}\right)\right]$,

124 where $\mathrm{z}^{*}\left(\mathrm{x}_{\mathrm{i}}\right)$ is the estimated value at $\mathrm{x}_{\mathrm{i}}$, and $\mathrm{z}\left(\mathrm{x}_{\mathrm{i}}\right)$ is the measured value at $\mathrm{x}_{\mathrm{i}}$.

125 The ratio of the mean squared error to the kriging variance was calculated as described in Eq. 126 (2):

$127 \quad S_{R}^{2}=\frac{1}{n} \sum_{i=1}^{n}\left[z *\left(x_{i}\right)-z\left(x_{i}\right)\right]^{2} / \sigma_{k}^{2}\left(x_{i}\right)$,

128 where $\sigma^{2} \mathrm{k}\left(\mathrm{x}_{\mathrm{i}}\right)$ is the theoretical estimation variance for the prediction of $\mathrm{z}^{*}\left(\mathrm{x}_{\mathrm{i}}\right)$.

129 The temporal evolution of contamination in rivers draining the main radioactive plume 130 was analyzed based on samples (described in section 2.2) taken after the main erosive events 131 which were expected to affect this area (i.e., the summer typhoons and the spring snowmelt). 132 During the first fieldwork campaign in November 2011, we travelled through the entire area 133 where access was unrestricted (i.e., outside the area of 20-km radius centered on FDNPP; Fig. 134 1b) and that potentially drained the main radioactive plume of Fukushima Prefecture, i.e. the 135 Abukuma River basin $\left(5200 \mathrm{~km}^{2}\right.$ ), and the coastal catchments (Mano, Nitta and Ota Rivers, 136 covering a total area of $525 \mathrm{~km}^{2}$ ). Those systems drain to the Pacific Ocean from an upstream 137 altitude of $1835 \mathrm{~m}$ a.s.1. Woodland (79\%) and cropland (18\%) represent the main land uses in the 138 area. Mean annual precipitation varies appreciably across the study area $(1100-2000 \mathrm{~mm})$, in 
139 response to the high variation of altitude and relief and the associated variable importance of snowfall.

141 During the second campaign (April 2012), based on the results of the first survey, the size

142 and the delineation of the study area were adapted for a set of practical, logistical and safety 143 reasons. Therefore, we targeted our sampling on the coastal catchments, where contamination 144 was the highest and where the application of the potential tracer that we identified was the most 145 promising.

\section{2.2. Sample collection}

147 We collected representative river sediment samples at exposed subaerial sites free of vegetation 148 on channel bars between 17 and 23 November 2011 (69 sampling sites), between 3 and 8 April 1492012 (40 sampling sites) and between 8 and 12 November 2012 (53 sampling sites) along the 150 main rivers draining the area and some of their major tributaries. At each sampling site, five to 151 ten subsamples of fine sediment that is likely to be deposited after the last major flood were 152 collected at several locations selected randomly down to the underlying coarser cobble or gravel 153 layer across a $10-\mathrm{m}^{2}$ surface by the means of a plastic trowel. They were subsequently used to 154 prepare a composite sample representative of the fine sediment deposited on the channel bars. 155 Bulk samples were dried, weighed, ground to a fine powder, packed into $15 \mathrm{ml}$ pre-tared 156 polyethylene specimen cups and sealed airtight. During the November 2012 fieldwork campaign, 157 we also had the opportunity to collect samples of the different layers representative of the 1.6-m 158 deep sediment sequence that accumulated behind Yokokawa dam on Ota River. 
160 Radionuclide activities $\left({ }^{134} \mathrm{Cs},{ }^{137} \mathrm{Cs},{ }^{110 \mathrm{~m}} \mathrm{Ag}\right)$ in all samples were determined by gamma 161 spectrometry using very low-background coaxial N- and P-types HPGe detectors with a relative 162 efficiency of ca. $50 \%$ at $1332 \mathrm{keV}$. Counting time of soil and sediment samples varied between $1638 \times 10^{4}$ and $200 \times 10^{4} \mathrm{~s}$ to allow the detection of ${ }^{110 \mathrm{~m}} \mathrm{Ag}$, which was present in much lower 164 activities in the samples $\left(2-2390 \mathrm{~Bq} \mathrm{~kg}\right.$ ) than ${ }^{134} \mathrm{Cs}$ and ${ }^{137} \mathrm{Cs}\left(500-1,245,000 \mathrm{~Bq} \mathrm{~kg}^{-1}\right)$. The $165{ }^{137} \mathrm{Cs}$ activities were measured at the $661 \mathrm{keV}$ emission peak. The ${ }^{134} \mathrm{Cs}$ activities were calculated 166 as the mean of activities derived from measurements conducted at $604 \mathrm{keV}$ and $795 \mathrm{keV}{ }^{228} \mathrm{Ac}$ 167 activities being negligible compared to ${ }^{134} \mathrm{Cs}$ activities) as both peaks are associated with the 168 largest gamma emission intensities of this radionuclide. The presence of ${ }^{110 \mathrm{~m}} \mathrm{Ag}$ was confirmed 169 by the detection of emission peaks at 885,937 and $1384 \mathrm{keV}$, but activities were calculated from 170 results obtained at $885 \mathrm{keV}$ only. Minimum detectable activities in ${ }^{110 \mathrm{~m}} \mathrm{Ag}$ for $24 \mathrm{~h}$ count times 171 reached $2 \mathrm{~Bq} \cdot \mathrm{kg}^{-1}$. Errors reached ca. $5 \%$ on ${ }^{134} \mathrm{Cs}$ and ${ }^{137} \mathrm{Cs}$ activities, and $10 \%$ on ${ }^{110 \mathrm{~m}} \mathrm{Ag}$ 172 activities at the $95 \%$ confidence level. All measured counts were corrected for background levels 173 measured at least every 2 months as well as for detector and geometry efficiencies. Results were 174 systematically expressed in Bq. $\mathrm{kg}^{-1}$ of dry weight. Counting efficiencies and quality assurance 175 were conducted using internal and certified International Atomic Energy Agency (IAEA) 176 reference materials prepared in the same specimen cups as the samples. All radionuclide 177 activities were decay corrected to the date of 14 June 2011 corresponding to the reference date of 178 the MEXT soil sampling campaign (used to compute the background contamination maps; see 179 section 2.1 for details) that was conducted just before the occurrence of typhoons in 2011 (July180 September).

\section{2.4. Calculation of a hillslope-to-sink hydro-sedimentary connectivity index}


A connectivity index was computed according to the method developed by Borselli et al. (2008)

183 to outline the spatial linkages and the potential connection between the sediment eroded from

184 hillslopes by runoff processes and the different storage areas identified within catchments. These grid provided by the Geospatial Information Authority of Japan (GSI) from the Ministry of Land, Infrastructure, Transport and Tourism (http://www.gsi.go.jp/). This DEM was computed by the GSI from data obtained by LIDAR airborne monitoring surveys.

Values of the weighting cropping and management parameter (the so-called ' $\mathrm{C}$-factor'), originally used in the USLE equation (USDA, 1978), were determined based on data found in the literature (Borselli et al., 2008; Kitahara et al., 2000; Yoshikawa et al., 2004) and applied to the different land use classes observed in the catchments and determined by a multitemporal and multispectral classification of SPOT-4 and SPOT-5 satellite images. SPOT-4 20-m resolution images dated from May 5, June 3 and September 10 2010, and SPOT-5 10-m resolution images dated from March 18, April 13 and 24, 2011. Differences in spectral responses (reflectances) between land uses allowed their spatial discrimination using ENVI 4.8 software. Then, based on their respective vegetal cover density during the spring season and their implications on soil 
sensitivity to erosion, three main land uses were identified (i.e., forests, croplands and built-up areas). Additionally, surface water areas (i.e., rivers, lakes, reservoirs) were delineated. The land use map was validated by generating a set $(n=150)$ of random points on the map and by comparing the classification output with the land use determined visually on available aerial photographs of the study area.

Hydrological drainage networks were derived from the GSI 10-m regular grid DEM 211 using hydrologic analysis tools available from ArcGIS10 (ESRI, 2011). As several sections of 212 hydrological networks did not coincide with the observed ones due to anthropogenic 213 modifications introduced for urban and rural landscape management, manual corrections were applied, based on the analysis of the SPOT-4, SPOT-5 images and maps provided by the ArcGIS 215 Online Map and Geoservices (ESRI, 2013).

\section{3. RESULTS AND DISCUSSION}

\section{3.1. Contamination of soils and river sediments}

218 The map of total cesium activities in soils of the study area was drawn by performing ordinary 219 kriging on the MEXT soil database (Fig. 1a, 2, 7). A pure nugget (sill=1.07*10 ${ }^{9} \mathrm{~Bq}^{2} \cdot \mathrm{kg}^{-2}$ ) and a 220 Gaussian model (Anisotropy $=357^{\circ}$, Major range $=69,100 \mathrm{~m}$, Minor range $=65,000 \mathrm{~m}$ and Partial 221 sill $=1.76^{*} 10^{9} \mathrm{~Bq}^{2} \cdot \mathrm{kg}^{-2}$ ) were nested into the experimental variogram (Fig. S1). This high nugget 222 value may be influenced by the limited spacing between MEXT sampling locations (ca. $200 \mathrm{~m}$ ) 223 that did not allow to assess the very close-range spatial dependence of the data, and by the 224 impact of vegetation cover variations on initial fallout interception. Nevertheless, the resulting 225 initial soil contamination map was considered to be relevant, as the mean error was close to zero 
$\left(-1.19 \mathrm{~Bq} \cdot \mathrm{kg}^{-1}\right)$ and the ratio of the mean squared error to the kriging variance remained close to unity (0.99).

Eight months after the accident, main anthropogenic gamma-emitting radionuclides detected in river sediment across the area were ${ }^{134} \mathrm{Cs},{ }^{137} \mathrm{Cs}$ and ${ }^{110 \mathrm{~m}} \mathrm{Ag}$. Trace levels in ${ }^{110 \mathrm{~m}} \mathrm{Ag}\left(t_{1 / 2}=250 \mathrm{~d}\right)$ were previously measured in soils collected near the power plants (Tagami et al., 2011; 232 Shozugawa et al., 2012) as well as in zooplankton collected off Japan in June 2011 (Buesseler et 233 al., 2012), but a set of systematic ${ }^{110 \mathrm{~m}} \mathrm{Ag}$ measurements conducted at the scale of entire 234 catchments had not been provided so far. This anthropogenic radioisotope is a fission product 235 derived from ${ }^{235} \mathrm{U},{ }^{238} \mathrm{U}$ or ${ }^{239} \mathrm{Pu}(\mathrm{JAEA}, 2010)$. It is considered to have a moderate radiotoxicity 236 as it was shown to accumulate in certain tissues such as in liver and brain of sheep and pig 237 (Oughton, 1989; Handl et al., 2000). This radioisotope was observed shortly after Chernobyl 238 accident but, in this latter context, it was rather considered as an activation product generated by 239 corrosion of silver coating of primary circuit components and by erosion of fuel rod coatings 240 containing cadmium (Jones et al., 1986). The presence of ${ }^{125} \mathrm{Sb}\left(\mathrm{t}_{1 / 2}=2.7 \mathrm{y}\right.$ ), which is also a 241 fission product, was also detected in most samples (1-585 Bq.kg-1; data not shown). All other 242 short-lived isotopes (e.g., ${ }^{131} \mathrm{I}\left[t_{1 / 2}=8 \mathrm{~d}\right],{ }^{136} \mathrm{Cs}\left[t_{1 / 2}=13 \mathrm{~d}\right],{ }^{129 \mathrm{~m}} \mathrm{Te}\left[t_{1 / 2}=34 \mathrm{~d}\right]$ ) that were found 243 shortly after the accident in the environment were not detected anymore in the collected sediment 244 samples (Shozugawa et al., 2012). By November 2011, ${ }^{134+137}$ Cs activities measured in river 245 sediment ranged between $500-1,245,000 \mathrm{~Bq} \mathrm{~kg}^{-1}$, sometimes far exceeding (by a factor 2 to 20 ) 246 the activity associated with the initial deposits on nearby soils (Fig. 2). This result confirms the 247 concentration of radionuclides in fine river sediments because of their strong particle-reactive 248 behaviour (Tamura, 1964; Whitehead, 1978; Motha et al., 2002). 
Those contamination levels are between 1 and 5 orders of magnitude higher than before

250 the accident (Fukuyama et al., 2010). As we could expect it, the highest contamination levels (total ${ }^{134+137} \mathrm{Cs}$ activities exceeding $100,000 \mathrm{~Bq} \cdot \mathrm{kg}^{-1}$ ) were measured in sediment collected along the coastal rivers (i.e., Mano and Nitta Rivers) draining the main radioactive plume (Fig. 2). Contamination levels were logically much lower in sediment collected along the Abukuma River that drains less contaminated areas. The analyses conducted by the Japanese Ministry of Environment (MoE) provided an additional temporal insight into contaminated sediment exports in this area. Our samples were collected in November 2011, whereas samples provided by MoE showed that contamination of sediment was systematically the highest in material collected in September 2011. The presence of contamination hotspots close to Fukushima City and behind a large dam located upstream of the city is likely due to the rapid wash-off of radionuclides on urban surfaces during the first series of rainfall events that followed the accident, to their concentration in urban sewers systems (Urso et al., 2013) and their subsequent export to the rivers. This rapid export of radionuclides shortly after the accident along the Abukuma River is confirmed by data collected by the MoE (Fig. 2) showing a peak of contamination in sediment collected in September 2011, and then a huge decrease to low activities even during snowmelt. Along the Hirose River, the snowmelt (in March 2012) led in contrast to an increase in sediment contamination.

270 extended sampling to the Ota River catchment, closer to FDNPP, where access was unauthorized during the first campaign (Fig. 1b). 


\subsection{Dispersion of radioactive sediment along river channels}

Whilst ${ }^{137} \mathrm{Cs}$ and ${ }^{134} \mathrm{Cs}$ gamma-emitting radioisotopes constitute by far the most problematic contaminants (with total activities in soils ranging from 50 to $1,110,000 \mathrm{~Bq} \cdot \mathrm{kg}^{-1}$ ), ${ }^{110 \mathrm{~m}} \mathrm{Ag}$ was also identified and measured in most samples (with activities ranging from 1 to $3150 \mathrm{~Bq} \cdot \mathrm{kg}^{-1}$ ). Because of these low activities, contribution of ${ }^{110 \mathrm{~m}} \mathrm{Ag}$ to the global dose rates was considered to be negligible. It appeared from the analysis of the MEXT soil database that the initial fallout pattern of ${ }^{110 \mathrm{~m}} \mathrm{Ag}$ displayed significant spatial variations that were not observed for the radiocaesium fallout pattern at the scale of the entire Fukushima Prefecture. Soil activities in ${ }^{110 \mathrm{~m}} \mathrm{Ag}$ were the highest within the main radiocaesium contamination plume as well as at several places along the coast located between 40 and $50 \mathrm{~km}$ to the north of the power plant (MEXT, 2011b).

Most interestingly, the 345 values of ${ }^{110 \mathrm{~m}} \mathrm{Ag}:{ }^{137} \mathrm{Cs}$ ratio in MEXT soil samples strongly varied across the entire region (0.0004-0.15 with a mean of 0.006; Fig. 4), whereas the 2200 values of ${ }^{134} \mathrm{Cs}:{ }^{137} \mathrm{Cs}$ ratio remained relatively stable across the contamination plume $(0.4-1.5$ with a mean value close to 0.9 ; data not shown). Fallout patterns of ${ }^{110 \mathrm{~m}} \mathrm{Ag}:{ }^{137} \mathrm{Cs}$ ratio in soils of Fukushima Prefecture provided a way to delineate three distinctive zones (Fig. 3, Table 1; i.e., 'eastern', 'southern' and 'western' zones). A Kruskal-Wallis H-test was conducted and it confirmed that these three zones were characterized by significantly different values of

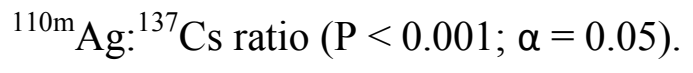

The differences in fallout patterns between ${ }^{110 \mathrm{~m}} \mathrm{Ag}$ and ${ }^{137} \mathrm{Cs}$ were most likely due to the fact that those radionuclides were released during different explosions affecting reactors containing different fuel assemblages (Schwantes et al., 2012). Furthermore, even though the 
overall chronology of the reactor explosions could be reconstructed (e.g., Le Petit et al., 2012), the subsequent radionuclide deposits are still imperfectly understood. To our knowledge, studies that modeled radionuclide deposits across Fukushima Prefecture dealt with ${ }^{131} \mathrm{I}$ and/or ${ }^{137} \mathrm{Cs}$ exclusively (e.g., Morino et al., 2013), and never with ${ }^{110 \mathrm{~m}} \mathrm{Ag}$. The single main operational difference between the FDNPP damaged reactors is that mixed-oxide (MOX) containing plutonium fuel that generates ${ }^{110 \mathrm{~m}} \mathrm{Ag}$ as a fission product was only used in reactor 3 (Le Petit et al., 2012), which may explain this different radionuclide deposition pattern.

In the coastal study area, the area covered by both 'western' and 'eastern' zones was unfortunately only large enough in the Nitta River catchment to be subsequently used to track the dispersion of contaminated sediment based on values of this ratio measured in soils as well as in river sediment (the area covered by the 'western' zone was too small in the Mano River catchment, and no soil sample was collected by MEXT in the 'western' part of the Ota River catchment; Fig.4). Descriptive statistics of ${ }^{110 \mathrm{~m}} \mathrm{Ag}:{ }^{137} \mathrm{Cs}$ values in the single Nitta catchment confirmed that the spatial variability of this ratio provided significantly different signatures in both 'western' and 'eastern' areas in this catchment (Table 2).

313 characterized by similar solid/liquid partition coefficient $\left(\mathrm{K}_{\mathrm{d}}\right)$ values $\left(9.0^{*} 10^{1}-4.4^{*} 10^{3}\right)$ in both 314 soils and sediment (IAEA, 1994; IPSN, 1994; Garnier-Laplace et al., 1997; Roussel-Debet and 315 Colle, 2005). Furthermore, it was demonstrated that ${ }^{110 \mathrm{~m}} \mathrm{Ag}$ is not mobile in soils (Alloway, 316 1995) and that it tends to concentrate in the few first centimeters of the soil uppermost surface, as 
317 it was reported for ${ }^{137} \mathrm{Cs}$ in Fukushima region (Kato et al., 2012; Handl et al., 2000; Shang and 318 Leung, 2003). Those literature data validate the relevance of using this ratio to discriminate 319 between sediment eroded from the mountain ranges located in the main contamination plume vs. 320 sediment mobilized from the coastal plains. This investigation is particularly crucial in the case 321 of coastal rivers in Fukushima Prefecture to guide the implementation of appropriate soil and 322 river management measures. Nitta River drains mountainous areas characterized by a high initial contamination to the Pacific Ocean, by flowing across coastal plains that were relatively spared by initial continental fallout but that are still currently densely populated (e.g. in Minamisoma town).

The relative contribution of each source in the composition of riverbed sediment collected 327 during the three sampling campaigns in the Nitta catchment was then quantified through the application of a binary mixing model. As an example, the relative contribution of 'western' 329 source area $X_{w}$ was determined from Eq. (3):

$$
X_{W}=\frac{\left(\frac{{ }^{110 m} A g}{{ }^{137} C S}\right)_{S}-\left(\frac{{ }^{110 m} A g}{{ }^{137} C S}\right)_{E}}{\left(\frac{{ }^{110 m} A g}{{ }^{137} C S}\right)_{W}-\left(\frac{{ }^{110 m} A g}{{ }^{137} C S}\right)_{E}} * 100,
$$

331 Where $X_{W}$ is the percentage fraction of the western source area, $\left({ }^{110 \mathrm{~m}} \mathrm{Ag}:{ }^{137} \mathrm{Cs}\right)_{\mathrm{W}}$ and $332\left({ }^{110 \mathrm{~m}} \mathrm{Ag}:{ }^{137} \mathrm{Cs}\right)_{\mathrm{E}}$ are the median values of ${ }^{110 \mathrm{~m}} \mathrm{Ag}:{ }^{137} \mathrm{Cs}$ ratio measured in MEXT soil samples 333 collected in the 'western' and the 'eastern' source areas of the Nitta catchment, i.e. 0.0024 and 3340.0057 respectively (Table 2), and $\left({ }^{110 \mathrm{~m}} \mathrm{Ag}:{ }^{137} \mathrm{Cs}\right)_{\mathrm{S}}$ is the isotopic ratio measured in the river 335 sediment sample. We did not include initial river sediment as a third end-member as the violent 336 typhoons that occurred between the accident (March 2011) and our first fieldwork campaign (November 
2011) likely flushed the fine riverbed sediment that was already present in the channels before the accident.

Application of the mixing model illustrates the very strong reactivity of this catchment and the entire flush of sediment stored in the river network during a one-year period only (Fig. 5). In November 2011, following the summer typhoons (i.e., Man-On on 20 July and Roke on 22 September that generated cumulative precipitation that reached between 215-310 mm across the study area), contaminated soil was eroded from upstream fields and supplied to the upstream sections of the rivers (Fig. 5a). Then, this sediment was exported to the coastal plains during the discharge increase generated by the snowmelt in March 2012, as illustrated by the measurements conducted on material sampled in April 2012 (Fig. 5b). Finally, sediment deposited within the river network was flushed by the typhoons that occurred during summer in 2012. Those typhoons were less violent than the ones that happened in 2011, and led to less intense erosion than during the previous year, but they were sufficiently powerful to increase river discharges, to export the sediment stored in the river channel and to replace it with material originating from closer areas (Fig. 5c).

This massive transfer of contaminated sediment reflects the strong seasonality of sediment fluxes in these rivers affected by both typhoons and spring snowmelt. Our results confirm that, by exporting contaminated particles originating from the main inland radioactive plume, coastal rivers are likely to have become a significant and perennial source of radionuclide contaminants to the Pacific Ocean off Fukushima Prefecture. This could at least partly explain the still elevated radionuclide levels measured in fish off Fukushima Prefecture (Buesseler et al., 2012). 
Quantification of the hydro-sedimentary connectivity between hillslopes and the identified sinks in the three coastal catchments provided additional information on the timing of sediment transfer processes and their preferential pathways observed along the investigated rivers (Fig. 6). Paddy fields located in the upstream part of both Nitta and Mano River catchments were well connected to the thalweg and they constituted therefore an important supply of contaminated material to the rivers or to small depressions located in the floodplain. In contrast, in the flat coastal plains of those catchments, large cultivated surfaces were poorly connected to the rivers. A distinct situation was observed in the Ota River catchment. In the upper part of this catchment, land use is dominated by forests that are much less erodible than cropland, but that could deliver contaminated material to the river during heavy rainfall (Fukuyama et al., 2010). Furthermore, the high slope gradients observed in this area may have led to the more frequent occurrence of mass movements in this area. This contaminated material was then stored in the large Yokokawa reservoir. In the downstream part of the Ota River catchment, paddy fields located in the vicinity of rivers were well connected to the watercourses which contrasts with the situation outlined in the coastal plains of the Mano and Nitta River catchments.

This transfer timing and preferential pathways are confirmed when we plot the contamination in total ${ }^{134+137} \mathrm{Cs}$ measured in sediment collected during the three fieldwork campaigns along the longitudinal profiles of the investigated rivers (Fig. 7). Overall, we observed a general decrease in the contamination levels measured between the first and the last campaign, especially in the Nitta River catchment (Fig. 7, left panels) where the difference is particularly spectacular along the upstream sections of the Nitta (Fig. 7; profile c-d) and Iitoi Rivers (Fig. 7; profile g-e). Our successive measurements suggest that there has been a 
progressive flush of contaminated sediment towards the Pacific Ocean. However, the mountain range piedmont and the coastal plains that have remained continuously inhabited constitute a potentially large buffer area that may store temporarily large quantities of radioactive contaminants from upstream areas. However, our data and the drawing of the longitudinal profiles suggest that this storage was of short duration in the river channels. A similar flush was observed between November 2011 and November 2012 along both Mano and Ota Rivers (Fig. 7; profiles $a-b$ and $i-j)$. They are equipped with dams at $20 \mathrm{~km}$ from the outlet for Nitta River, and at 16 and $12 \mathrm{~km}$ from the outlet for the Ota river. Only the finest - and most contaminated material is exported from their reservoirs, as suggested by the very high ${ }^{134+137} \mathrm{Cs}$ activities measured in sediment collected just downstream of the dams (Fig. 7; profiles a-b and i-j). Those reservoirs stored very large quantities of contaminated sediment, as illustrated by the contamination profile documented in sediment accumulated behind Tetsuzen dam (Fig. 8). Identification of a $10-\mathrm{cm}$ sediment layer strongly enriched in ${ }^{134+137} \mathrm{Cs}\left(308,000 \mathrm{~Bq} \cdot \mathrm{kg}^{-1}\right)$ and overlaid by a more recent and less contaminated layer (120,000 Bq.kg $\left.{ }^{-1}\right)$ shows that Fukushima accident produced a distinct geological record that will be useful for sediment dating and estimation of stocks of contaminated material in this region of Japan during the next years and decades.

\section{Conclusions}

The succession of typhoons and snowmelt events during the 20 months that followed FDNPP accident led to the rapid and massive dispersion of contaminated sediment along coastal rivers draining the catchments located in the main radioactive pollution plume. In this unique post- 
accidental context, the absence of continuous river monitoring has necessitated the combination of indirect approaches (mapping and tracing based on radioisotopic ratios, connectivity assessment) to provide this first overall picture of early sediment dispersion in Fukushima coastal catchments. These results obtained on riverbed sediment should be compared to the measurements conducted on suspended sediment that are being collected since December 2012.

409 The combination of those measurements with discharge and suspended sediment concentration 410 data will also allow calculating exports of contaminated sediment to the Pacific Ocean. Our 411 results showing the rapid dispersion of contaminated sediment from inland mountain ranges 412 along the coastal river network should also be compared to the ones obtained with the 413 conventional fingerprinting technique based on the geochemical signatures of contrasted 414 lithologies. Fukushima coastal catchments investigated by this study are indeed constituted of 415 contrasted sources (volcanic, plutonic and metamorphic sources in upper parts vs. sedimentary 416 sources in the coastal plains). This unique combination of surveys and techniques will provide 417 very important insights into the dispersion of particle-borne contamination in mountainous 418 catchments that are particularly crucial in this post-accidental context, but that will also be 419 applicable in other catchments of the world where other particle-borne contaminants are 420 problematic. 


\section{ACKNOWLEDGMENTS}

This work is a part of the TOFU (Tracing the environmental consequences of the Tohoku earthquake-triggered tsunami and Fukushima accident) project, funded by the joint French National Research Agency-Flash Japon (ANR- 11-JAPN-001) and Japan Science and Technology agency/J-RAPID programme. Support and data provided by the Japanese Ministry of Environment (http://www.env.go.jp/en/) were greatly appreciated. LSCE (Laboratoire des Sciences du Climat et de 1'Environnement) contribution No.X. SPOT-Image and the French national CNES-ISIS (Centre National d'Etudes Spatiales - Incentive for the Scientific use of Images from the SPOT system) program are also acknowledged for providing the SPOT data. 


\section{REFERENCES}

Achim, P., Monfort, M., Le Petit, G., Gross, P., Douysset, G., Taffary, T., Blanchard, X., Moulin, C., 2012. Analysis of radionuclide releases from the Fukushima Dai-ichi Nuclear Power Plant accident - Part II. Pure and Applied Geophysics. DOI 10.1007/s00024-012-0578-1.

433 Alloway, B. J, Ed., 1995. Heavy Metals in Soils, $2^{\text {nd }}$ ed.; Blackie Academic and Professional.

434 Borselli, L., Cassi, P., Torri, D., 2008. Prolegomena to sediment and flow connectivity in the landscape: 435 A GIS and field numerical assessment. Catena 75, 268-277.

436 Buesseler, K., Aoyama, M., Fukasawa, M., 2011. Impacts of the Fukushima nuclear power plants on 437 marine radioactivity. Environ. Sci. Technol. 45, 9931-9935.

438 Buesseler, K. O., 2012. Fishing for answers off Fukushima. Science 338, 480-482.

439 Buesseler, K.O., Jayne, S.R., Fisher, N.S., Rypina, I.I., Baumann, H., Baumann, Z., Breiera, C.F., 440 Douglass, E.M., George, J., Macdonald, A.M., Miyamoto, H., Nishikawa, J., Pike, S.M., Yoshida, S., 441 2012. Fukushima-derived radionuclides in the ocean and biota off Japan. Proc. Natl. Acad. Sci. USA 109, $4425984-5988$.

443 Burns, P.C., Ewing, R.C., Navrotsky, A., 2012. Nuclear fuel in a reactor accident. Science 335, 11844441188.

445 Chilès, J.P.; Delfiner, P., 1988. Geostatistics: Modeling Spatial Uncertainty; Wiley: New York. 
Chino, M., Nakayama, H., Nagai, H., Terada, H., Katata, G., Yamazawa, H., 2011. Preliminary estimation of release amounts of ${ }^{131} \mathrm{I}$ and ${ }^{137} \mathrm{Cs}$ accidentally discharged from the Fukushima Daiichi nuclear power plant into the atmosphere. J. Nucl. Sci. Technol. 48, 1129-1134.

Endo, S., Kimura, S., Takatsuji, T., Nanasawa, K.,Imanaka, T., Shizuma, K., 2012. Measurement of soil contamination by radionuclides due to the Fukushima Dai-ichi Nuclear Power Plant accident and associated estimated cumulative external dose estimation. J. Environ. Radioact. 111, 18-27.

ESRI, 2011. ArcGIS Desktop: Release 10. Redlands, CA: Environmental Systems Research Institute.

454 ESRI, 2013. ArcGIS Online Map and Geoservices. http://www.esri.com/software/arcgis/arcgisonline-map-and-geoservices/map-services

456 Fukuyama, T., Onda, Y., Gomi, T., Yamamoto, K., Kondo, N., Miyata, S., Kosugi, K., Mizugaki, S., 457 Tsubonuma, N., 2010. Quantifying the impact of forest management practice on the runoff of the surface458 derived suspended sediment using fallout radionuclides. Hydrol. Process. 24, 596-607.

459 Garnier-Laplace, J., Fournier-Bidoz, V., Baudin, J., 1997. État des connaissances sur les échanges entre 460 l'eau, les matières en suspension et les sédiments des principaux radionucléides rejetés par les centrales 461 nucléaires en eau douce. Radioprotection 3 (1), 49-71.

462 Garnier-Laplace, J., Beaugelin-Seiller, K., Hinton, T.G., 2011. Fukushima wildlife dose reconstruction 463 signals ecological consequences. Environ. Sci. Technol. 45, 5077-5078.

464 Goovaerts, P., 1997. Geostatistics For Natural Resources Evaluation; Oxford Univ. Press: Oxford, U.K.

465 Handl, J., Kallweit, E., Henning, M., Szwec, L., 2000. On the long-term behaviour of ${ }^{110 \mathrm{~m}}$ Ag in the soilplant system and its transfer from feed to pig. J. Environ. Radioact. 48 (2), 159-170. 
IAEA, 1994. Handbook of Parameter Values for the Prediction of Radionuclide Transfer in the

Terrestrial and Freshwater Environment; IAEA Technical Report series TRS-364. International Atomic Energy Agency, Vienna. http://www-pub.iaea.org/MTCD/publications/PDF/trs472_web.pdf.

IPSN, 1994. Etudes bibliographiques sur les échanges entre l'eau les matières en suspension et les sédiments des principaux radionucléides rejetés par les centrales nucléaires; Rapport IPSN, SERE 94/073; Institut de Protection et de Sûreté Nucléaire : Cadarache.

Institut de Radioprotection et de Sûreté Nucléaire (IRSN), 2012. Bilan des conséquences de l'accident de Fukushima sur l'environnement au Japon, un an après l'accident (28/02/2012). http://www.irsn.fr/FR/base_de_connaissances/Installations_nucleaires/La_surete_Nucleaire/Lesaccidents-nucleaires/accident-fukushima-2011/fukushima-1-an/Documents/IRSN_Fukushima_SyntheseEnvironnement_28022012.pdf.

Kato, H., Onda, Y., Teramage, M., 2012. Depth distribution of ${ }^{137} \mathrm{Cs},{ }^{134} \mathrm{Cs}$, and ${ }^{131} \mathrm{I}$ in soil profile after Fukushima Dai-ichi Nuclear Power Plant Accident. J. Environ. Radioact. 111, 59-64.

Japanese Atomic Energy Agency (JAEA), 2010. Ag-110m - Nuclide Information. http://wwwndc.jaea.go.jp/cgi-bin/nuclinfo2010?47,110

Jones, G.D., Forsyth, P.D., Appleby, G.B., 1986. Observation of ${ }^{110 \mathrm{~m}} \mathrm{Ag}$ in Chernobyl fallout. Nature $322,313$.

Kinoshita, N., Sueki, K., Sasa, K., Kitagawa, J., Ikarashi, S., Nishimura, T., Wong, Y.S., Satou, Y., Handa, K., Takahashi, T., Sato, M., Yamagata, T., 2011. Assessment of individual radionuclide distributions from the Fukushima nuclear accident covering central-east Japan. Proc. Natl. Acad. Sci. USA $108,19526-19529$.

Kitahara, H., okura, Y., Sammori, T., Kawamami, A., 2000. Application of Universal Soil Loss Equation (USLE) to Mountainous Forests in Japan. Journal of Forest Research 5, 231-236. 
Koarashi, J., Atarashi-Andoh, M., Matsunaga, T., Sato, T., Nagao, S., Nagai, H., 2012. Factors affecting

491 vertical distribution of Fukushima accident-derived radiocesium in soil under different land-use 492 conditions. Science of the Total Environment 431, 392-401.

493 Le Petit, G., Douysset, G., Ducros, G., Gross, P., Achim, P., Monfort, M., Raymond, P., Pontillon, Y., 494 Jutier, C., Blanchard, X., Taffary, T., Moulin, C., 2012. Analysis of Radionuclide Releases from the 495 Fukushima Dai-Ichi Nuclear Power Plant Accident - Part I. Pure and Applied Geophysics. DOI $49610.1007 / \mathrm{s} 00024-012-0581-6$.

497 Masson, O., et al., 2011. Tracking of airborne radionuclides from the damaged Fukushima Dai-ichi 498 nuclear reactors by European networks. Environ. Sci. Technol. 45, 7670-7677.

499 Matsunaga, T., Koarashi, J., Atarashi-Andoh, M., Nagao, S., Sato, T., Nagai, H., 2013. Comparison of the 500 vertical distributions of Fukushima nuclear accident radiocesium in soil before and after the first rainy 501 season, with physicochemical and mineralogical interpretations. Science of the Total Environment 447, $502 \quad 301-314$

503 Meybeck, M., 2003. Global analysis of river systems: from Earth system controls to Anthropocene 504 syndromes. Phil. Trans. R. Soc. Lond. B 358, 1935-1955.

505 Ministry of Education, Culture, Sports Science and Technology (MEXT), 2011a. Preparation of 506 distribution map of radiation doses, etc. (Map of radioactive cesium concentration in soil) by MEXT. 507 http://radioactivity.mext.go.jp/en/contents/5000/4165/24/1750_083014.pdf

508 Ministry of Education, Culture, Sports Science and Technology (MEXT), 2011b. Preparation of 509 Distribution Map of Radiation Doses, etc. (Maps of Concentration of Tellurium 129m and Silver $510 \quad 110 \mathrm{~m}$ in Soil) by MEXT.

511 http://radioactivity.mext.go.jp/en/contents/5000/4168/24/1750_1031e_2.pdf 

516 of radiocesium from the Fukushima Daiichi nuclear power plant accident. Environmental Science and 517 Technology. DOI 10.1021/es304620x.

518 Motha, J.A., Wallbrink, P.J., Hairsine, P.B., Grayson, R.B., 2002. Tracer properties of eroded sediment 519 and source material. Hydrol. Process. 16, 1983-2000.

520 Mouri, G., Shiiba, M., Hori, T., Oki, T., 2011. Modeling reservoir sedimentation associated with an 521 extreme flood and sediment. Geomorphology 125, 263-270.

522 Nuclear Safety Commission of Japan (NSC), 2011. Trial estimation of emission of radioactive materials $523 \quad\left({ }^{131} \mathrm{I},{ }^{137} \mathrm{Cs}\right)$ into the atmosphere from Fukushima Dai-ichi nuclear power station. 524 http://www.nsc.go.jp/NSCenglish/geje/2011\%200412\%20press.pdf.

525 Oughton, D., 1989. The environmental chemistry of radiocaesium and other nuclides. PhD thesis, 526 University of Manchester.

527 Rogowski, A.S., Tamura, T., 1965. Movement of ${ }^{137}$ Cs by runoff, erosion and infiltration on the alluvial 528 Captina silt loam. Health Physics 11(12), 1333-1340.

529 Roussel-Debet, S., Colle, C., 2005. Comportement de radionucléides (Cs, I, Sr, Se, Tc) dans le sol : proposition de valeurs de $\mathrm{K}_{\mathrm{d}}$ par défaut. Radioprotection 40 (2), 203-229.

531 Schwantes, J.M., Orton, C.R., Clark, R.A., 2012. Analysis of a nuclear accident: fission and activation 532 product releases from the Fukushima Daiichi nuclear facility as remote indicators of source identification, 533 extent of release, and state of damaged spent nuclear fuel. Environ. Sci. Technol. 46, 8621-8627. 
Shang, Z.R.; Leung, J.K.C, 2003. ${ }^{110 \mathrm{~m}} \mathrm{Ag}$ root and foliar uptake in vegetables and its migration in soil. $J$. Environ. Radioact. 65 (3), 297-307.

Shozugawa, T.; Nogawa, N.; Matsuo, M., 2012. Deposition of fission and activation products after the Fukushima Dai-ichi nuclear power plant accident. J. Env. Pol. 163, 243-247.

538 Simons, M., Minson, S.E., Sladen, A., Ortega, F., Jiang, J., Owen, S.E., Meng, L., Ampuero, J.P., Wei, S., 539 Chu, R., Helmberger, D.V., Kanamori, H., Hetland, E., Moore, A.W., Webb, F.H., 2011. The 2011 540 Magnitude 9.0 Tohoku-Oki Earthquake: Mosaicking the Megathrust from Seconds to Centuries. Science $541332,1421-1425$.

542 Simpson, H.J., Olsen, C.R., Trier, R.M., Williams, S.C, 1976. Man-made radionuclides and sedimentation 543 in the Hudson River estuary. Science 194, 179-183.

544 Stohl, A., Seibert, P., Wotawa, G., Arnold, D. , Burkhart, J.F. , Eckhardt, S., Tapia, C. , Vargas, A. , 545 Yasunari, T.J., 2012. Xenon-133 and caesium-137 releases into the atmosphere from the Fukushima Dai546 ichi nuclear power plant: determination of the source term, atmospheric dispersion, and deposition. Atmos. Chem. Phys. 12, 2313-2343.

548 Tagami, K., Uchida, S., Uchihori, Y., Ishii, N., Kitamura, H., Shirakawa, Y., 2011. Specific activity and 549 activity ratios of radionuclides in soils collected about $20 \mathrm{~km}$ from the Fukushima Daiichi nuclear power 550 plant: Radionuclide release to the south and southwest. Sci. Total Environ. 409, 4885-4888.

551 Tamura, T., 1964. Consequences of activity release: selective sorption reactions of cesium with soil 552 minerals. Nucl. Safety 5, 262-268.

553 Ueda, S., Hasegawa, H., Kakiuchi, H., Akata, N., Ohtsuka, Y., Hisamatsu, S., 2013. Fluvial discharges of 554 radiocaesium from watersheds contaminated by the Fukushima Dai-ichi Nuclear Power Plant accident, 555 Japan. Journal of Environmental Radioactivity 118, 96-104. 
Urso, L., Kaiser, J.C., Andersson, K.G., Andorfer, H., Angermair, G., Gusel, C., Tandler, R., 2013. Modeling of the fate of radionuclides in urban sewer systems after contamination due to nuclear or radiological incidents. Journal of Environmental Radioactivity 118, 121-127.

USDA, 1978. Predicting rainfall erosion losses; in A Guide to Conservation Planning. USDA Agriculture Handbook No.537, pp.58.

Van Oost, K., Quine, T.A., Govers, G., De Gryze, S., Six, J., Harden, J.W., Ritchie, J.C., McCarty, G.W., Heckrath, G., Kosmas, C., Giraldez, J.V., Marques da Silva, J.R., Merckx, R., 2007. The impact of agricultural soil erosion on the global carbon cycle. Science 318(5850), 626-629.

566 Winiarek, V., Bocquet, M., Saunier, O., Mathieu, A., 2012. Estimation of errors in the inverse modeling 567 of accidental release of atmospheric pollutant: application to the reconstruction of the cesium-137 and 568 iodine-131 source terms from the Fukushima Daiichi power plant. J. Geophys. Res. 117, D05122; DOI 10.1029/2011JD016932.

Yasunari, T.J., Stohl, A., Hayano, C., Burkhart, J.F., Eckhardt, S., Yasunari, T., 2011. Cesium-137 571 deposition and contamination of Japanese soils due to the Fukushima nuclear accident. Proc. Natl. Acad. 572 Sci. USA 108, 19530-19534.

573 Yoshikawa, S., Yamamoto, H., Hanano, Y., Ishihara, A., 2004. Hilly-Land Soil Loss Equation (HSLE) 574 for Evaluation of Soil Erosion Caused by the Abandonment of Agricultural Practices. JARQ 38, 21-29. 575 http://www.jircas.affrc.go.jp. 


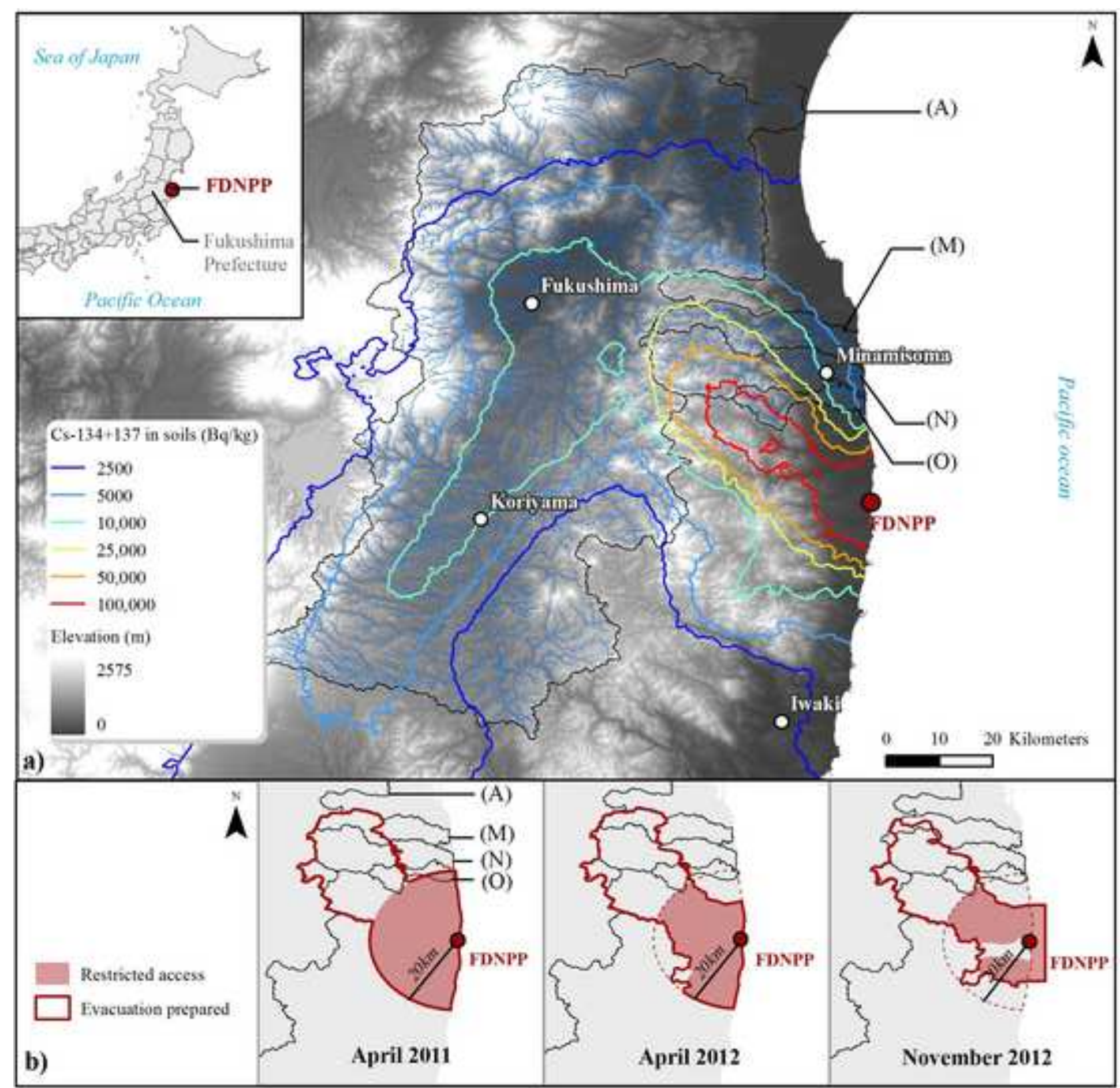

a) of

b)

April 2011

April 2012

November 2012 


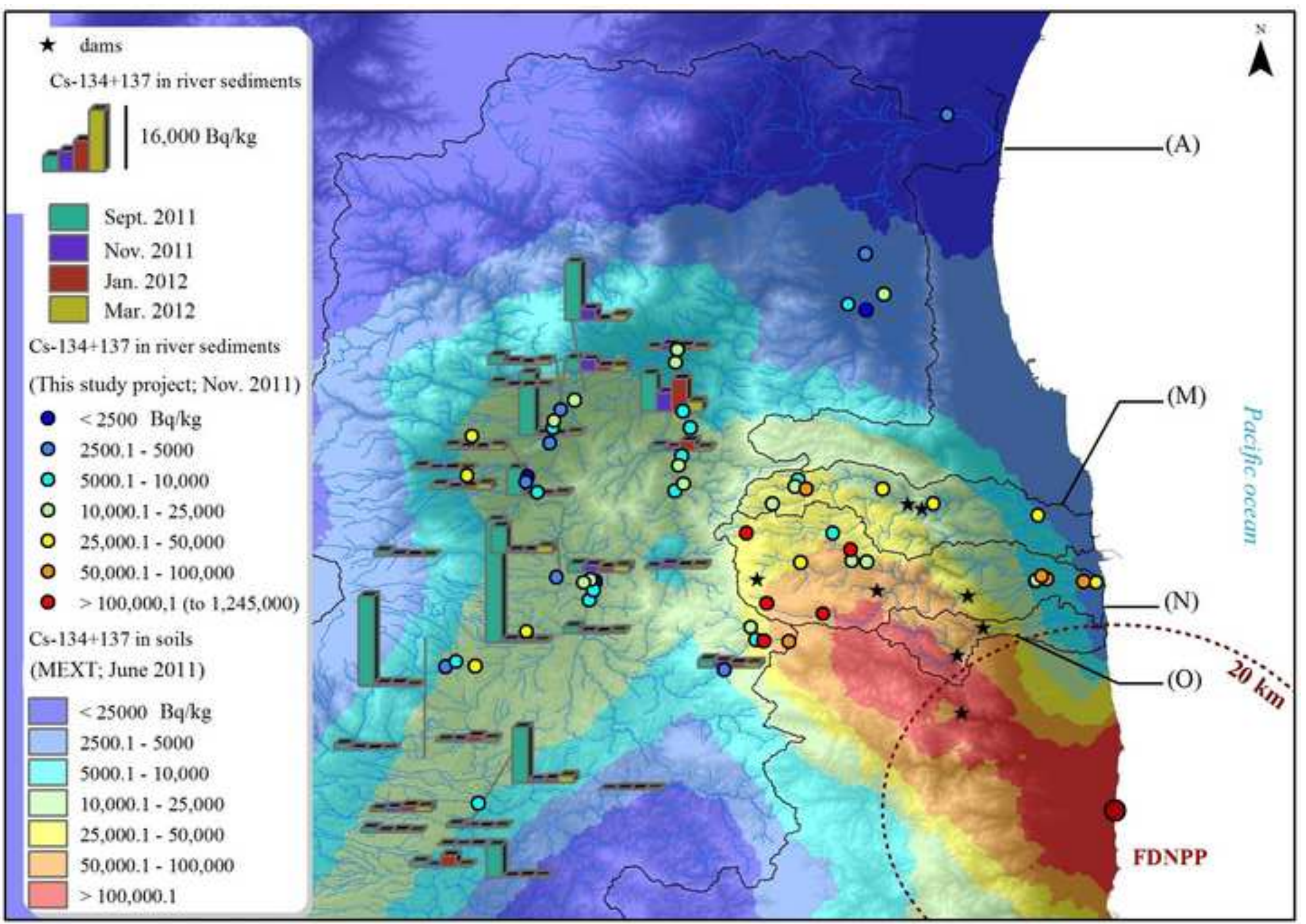


Click here to download high resolution image

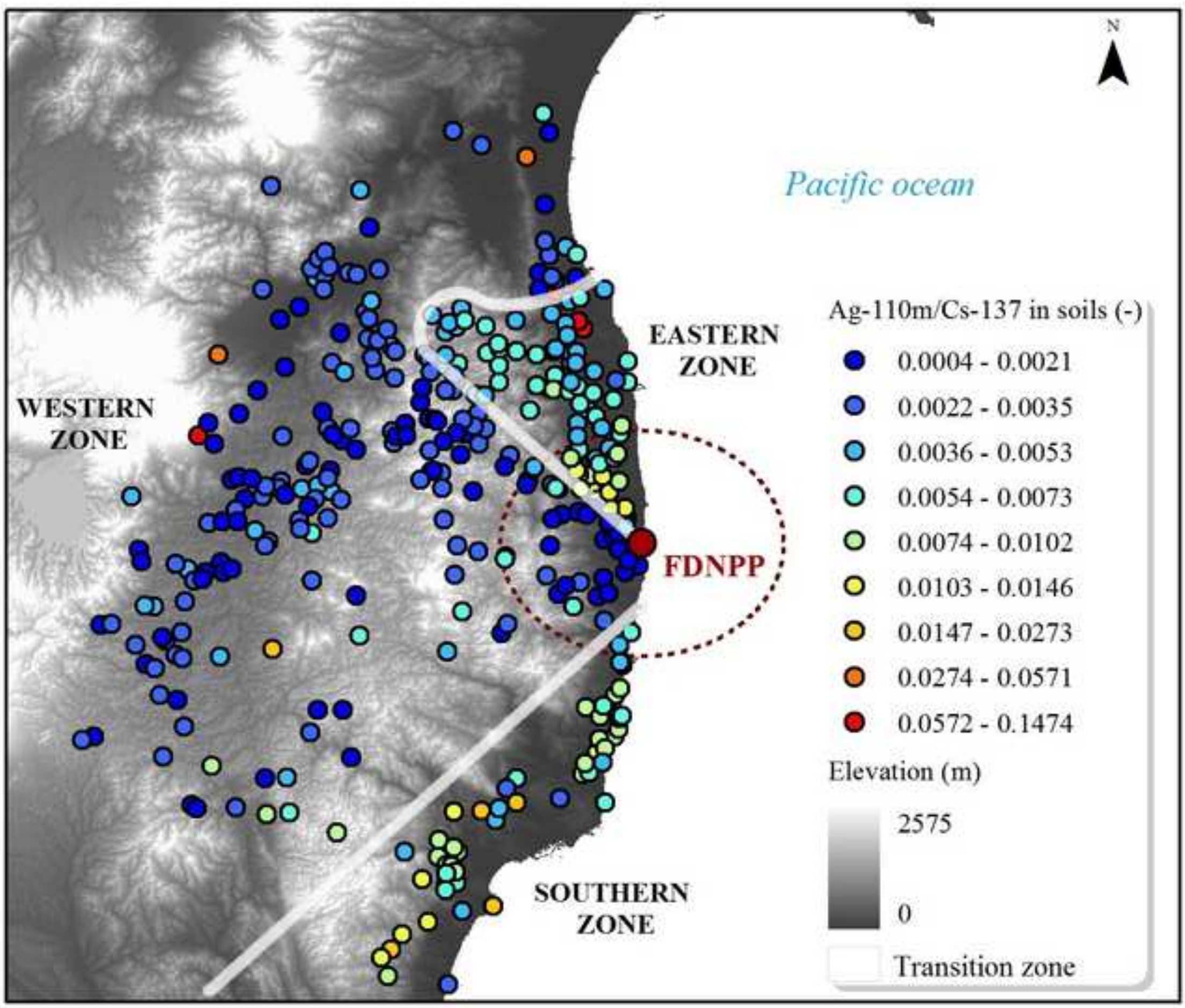




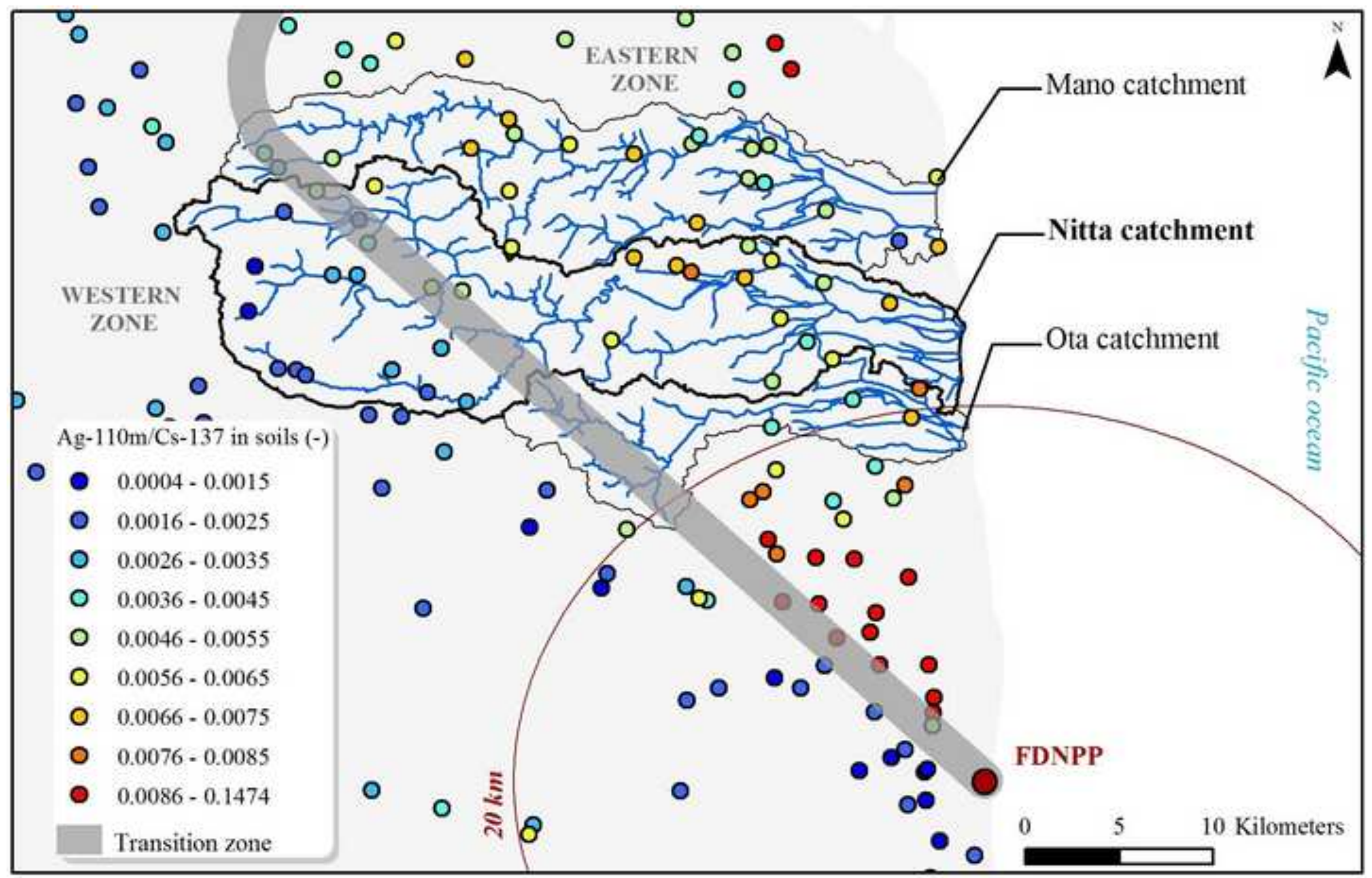


Click here to download high resolution image
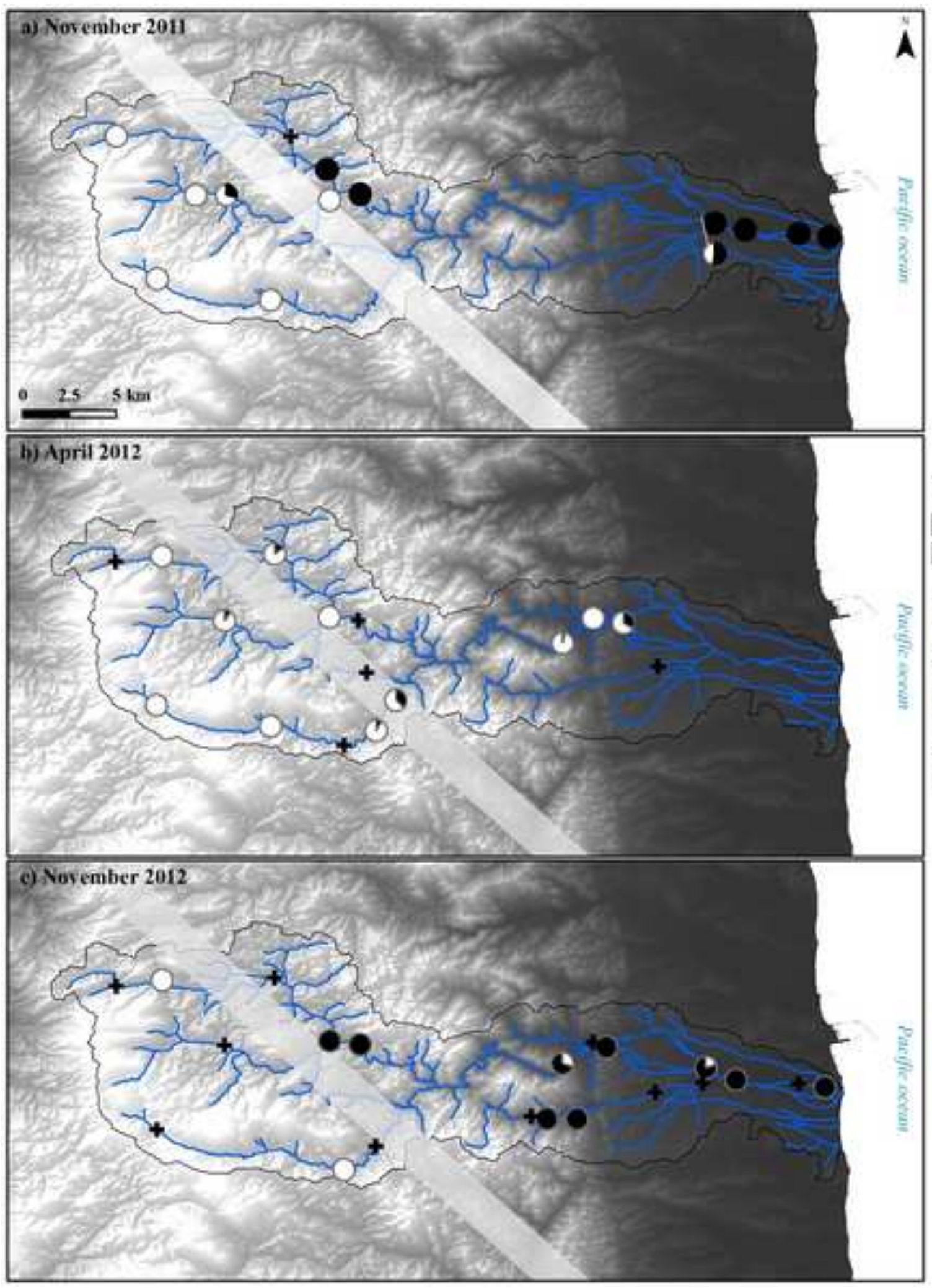

Relative controbution in sediment composition of Western zone Fastern poos Sediment samples where

$+\mathrm{Ag} \cdot 110 \mathrm{~m}$ was nos detertable

Hevatine (m)

1165
0

Transition zoes 
Figure 6

Click here to download high resolution image

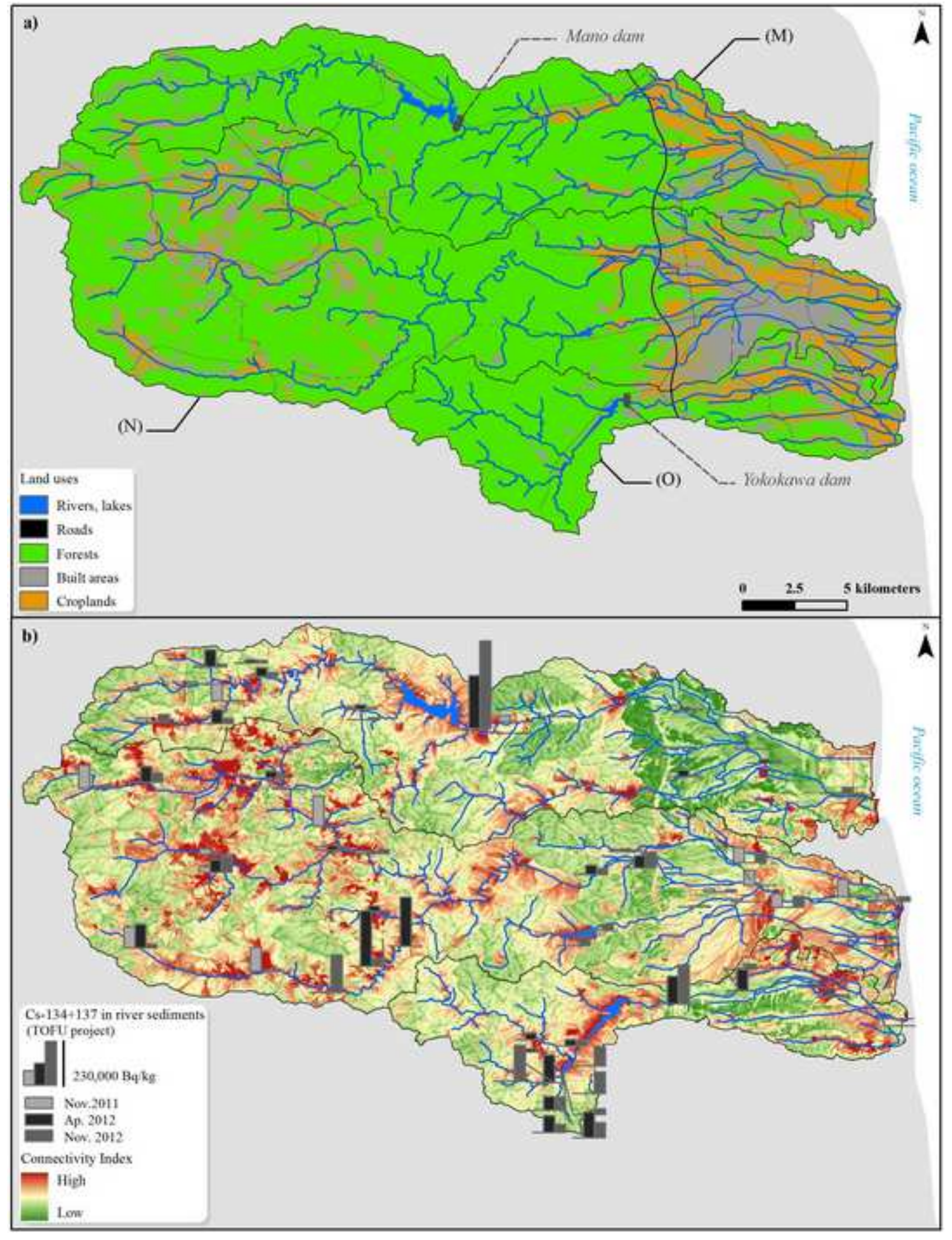

Cs. $134+137$ in river sediments (roft peojest)

i. $230,000 \mathrm{~Bq} / \mathrm{kg}$

$\square$ Now.2011

Now 2012

Connectivity Index

Low 


\section{NITTA catchment}
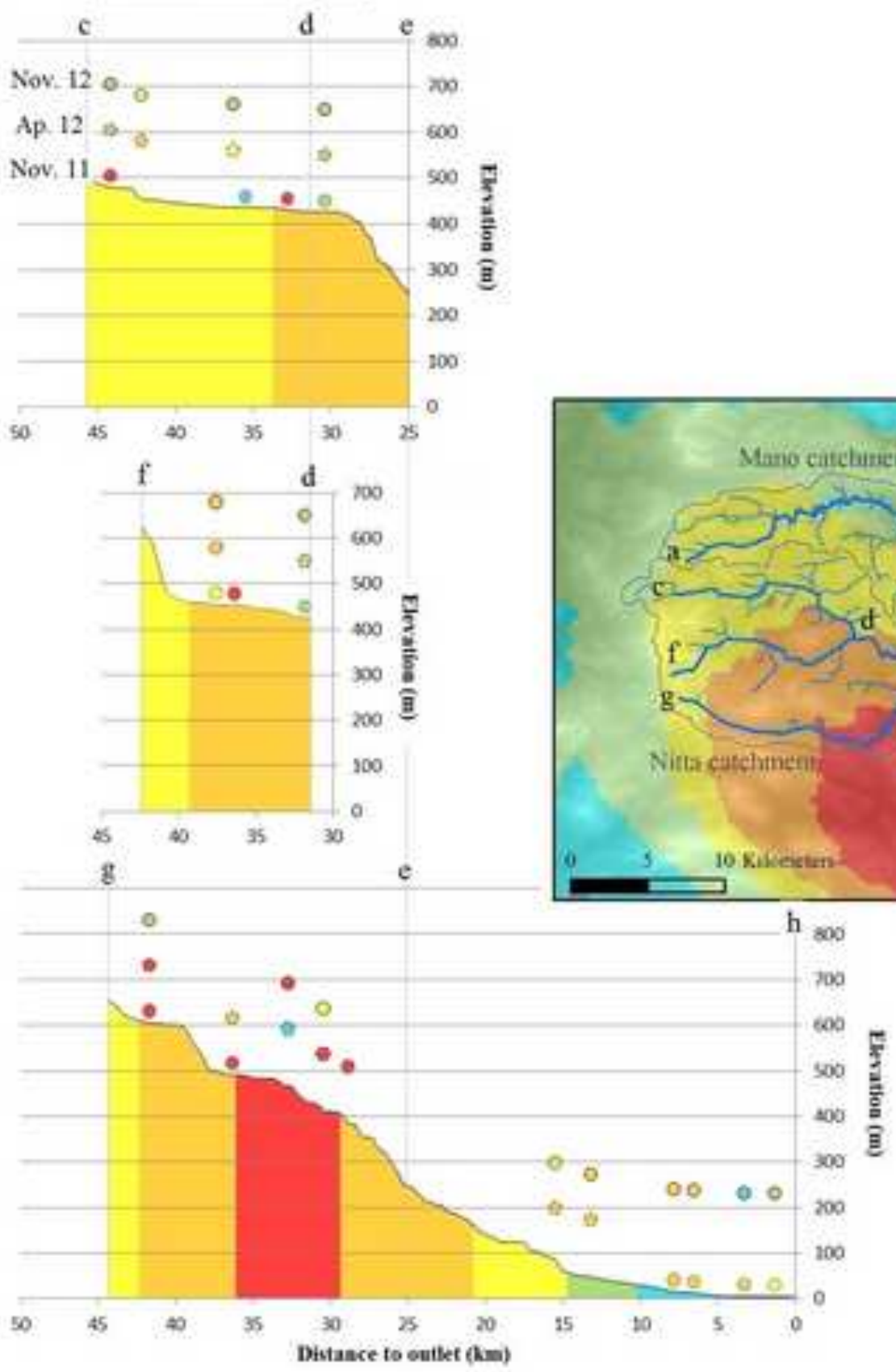

MANO catchment
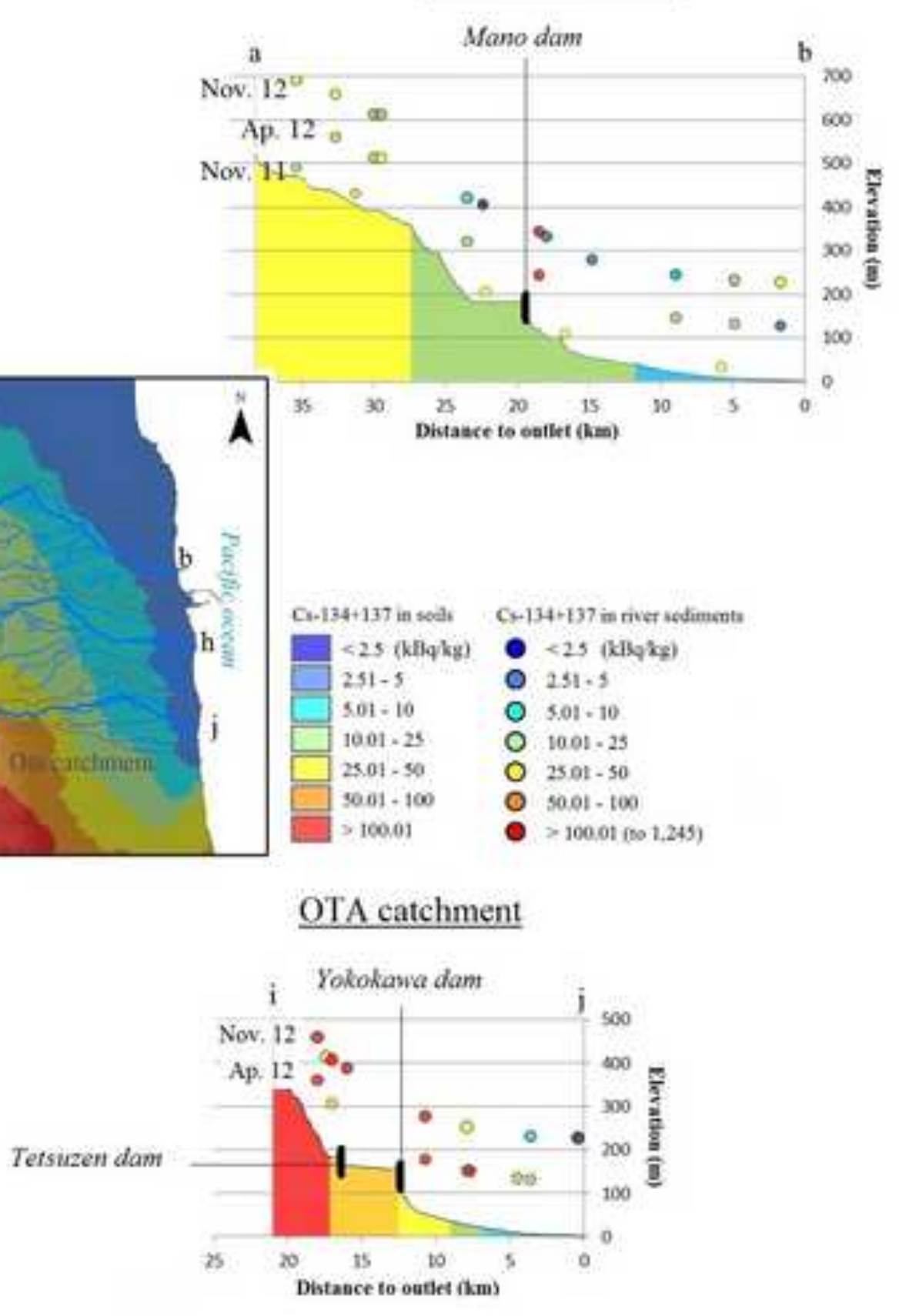

OTA catchment

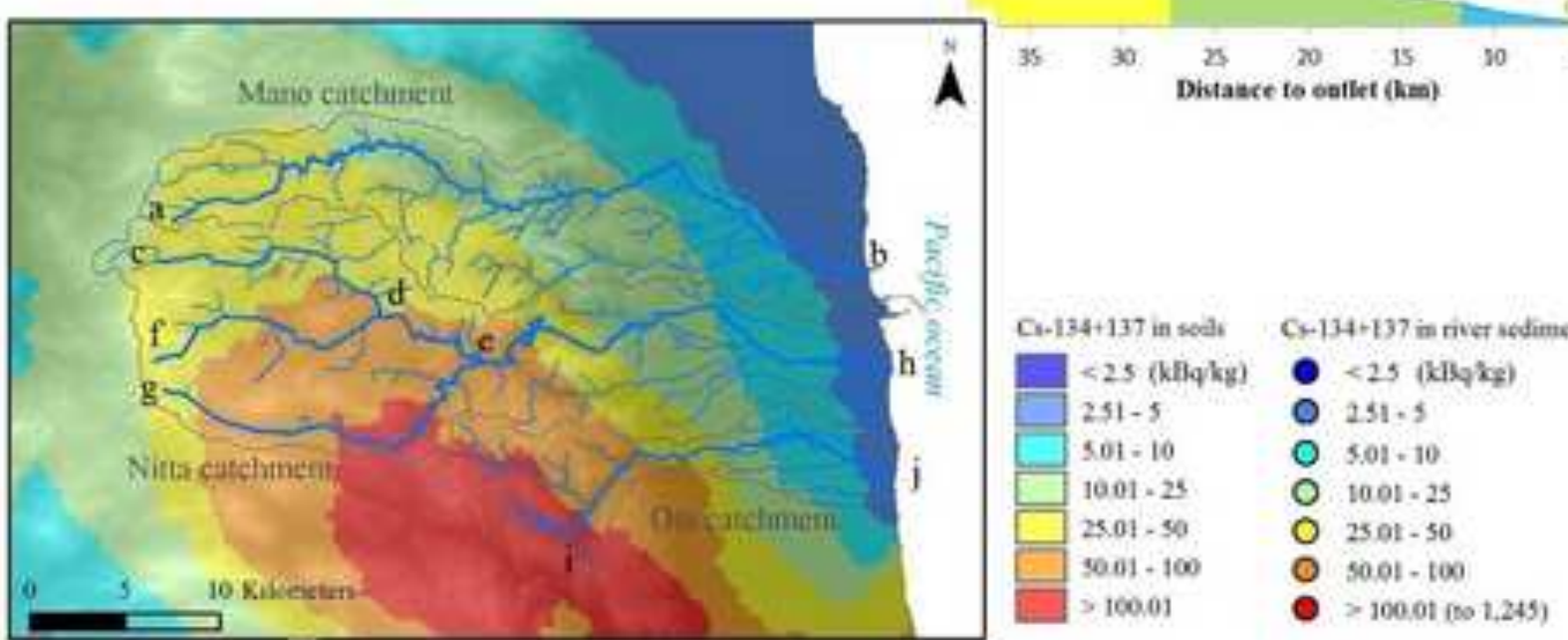

音

管 
Figure 8
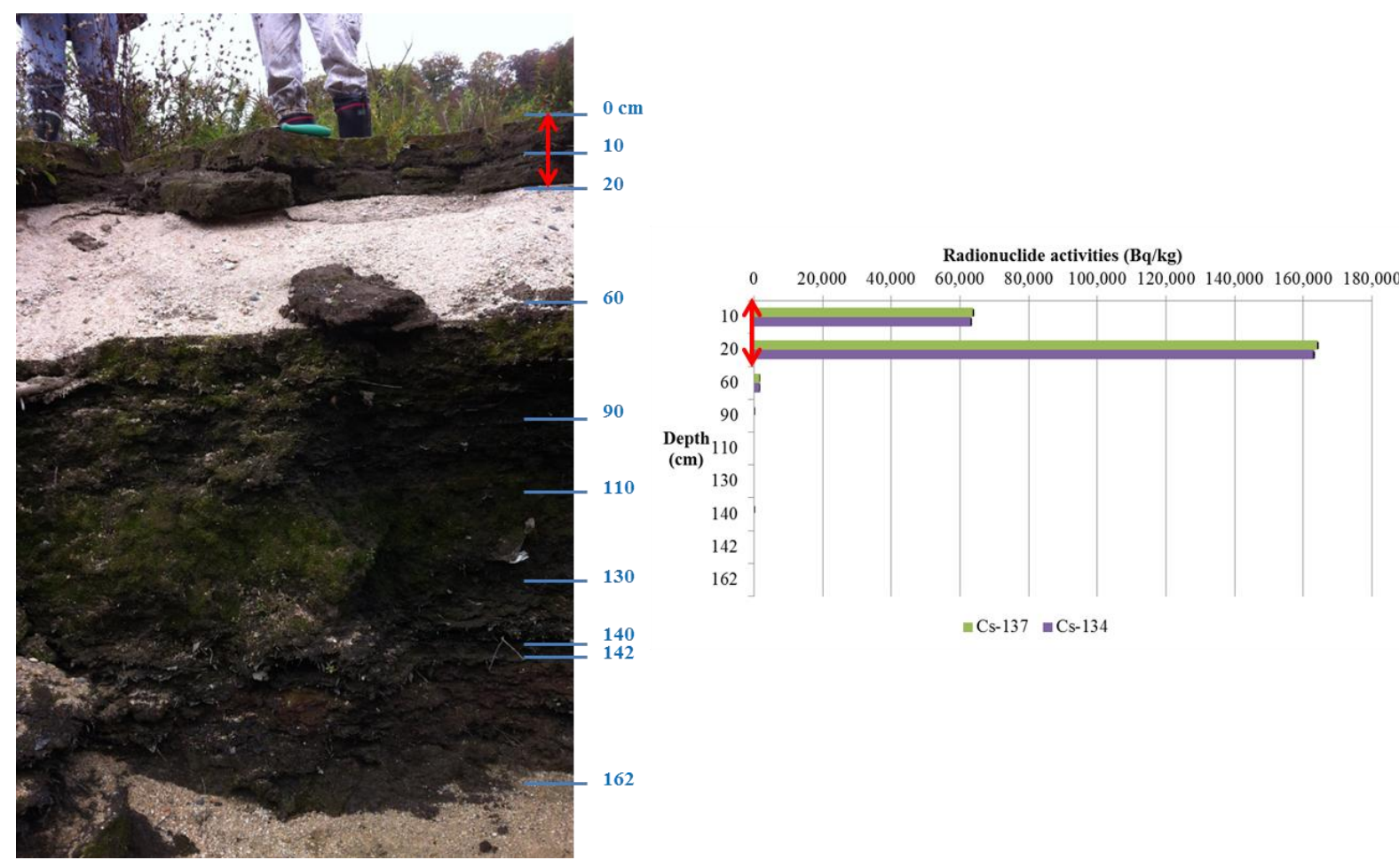

=Cs-137 | - Cs-134 
Table 1. Descriptive statistics of ${ }^{110 \mathrm{~m}} \mathrm{Ag}:{ }^{137} \mathrm{Cs}$ ratio values measured in bulk soil under the authority of MEXT across Fukushima Prefecture (data located in a transition zone of 2-km width where there was a short-scale variability in ${ }^{110 \mathrm{~m}} \mathrm{Ag}:{ }^{137} \mathrm{Cs}$ values between the 'western', the 'eastern' and the 'southern' zones were excluded).

\begin{tabular}{|l|c|c|c|}
\hline Dataset & Western zone & Eastern zone & Southern zone \\
\hline Count (-) & 209 & 71 & 51 \\
\hline Minimum (-) & 0.0004 & 0.0025 & 0.0024 \\
\hline Maximum (-) & 0.1474 & 0.0969 & 0.0273 \\
\hline Mean (-) & 0.0038 & 0.0090 & 0.0086 \\
\hline S.D. (-) & 0.0112 & 0.0145 & 0.0044 \\
\hline Median (-) & 0.0024 & 0.0058 & 0.0081 \\
\hline
\end{tabular}

Table 2. Descriptive statistics of ${ }^{110 \mathrm{~m}} \mathrm{Ag}:{ }^{137} \mathrm{Cs}$ ratio values measured in bulk soil under the authority of MEXT within the Nitta catchment (data located in the transition zone were excluded).

\begin{tabular}{|l|c|c|}
\hline Dataset & $\begin{array}{l}\text { Western zone } \\
\text { (Nitta catchment) }\end{array}$ & $\begin{array}{l}\text { Eastern zone } \\
\text { (Nitta catchment) }\end{array}$ \\
\hline Count (-) & 12 & 14 \\
\hline Minimum (-) & 0.0010 & 0.0041 \\
\hline Maximum (-) & 0.0035 & 0.0082 \\
\hline Mean (-) & 0.0023 & 0.0059 \\
\hline S.D. (-) & 0.0008 & 0.0012 \\
\hline Median (-) & 0.0024 & 0.0057 \\
\hline
\end{tabular}




\section{Graphical abstract}

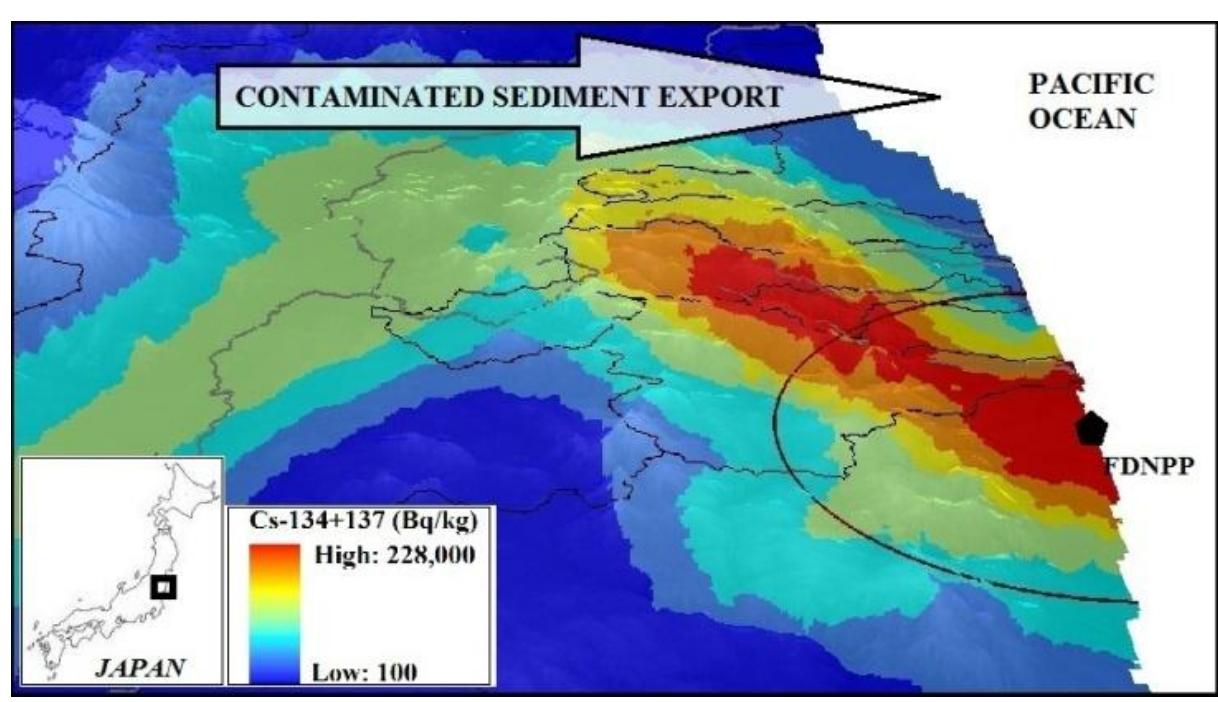


e-components Supplementary Fig. 1
Click here to download e-components: FigS1.doc

Click here to download e-components: Figs1.doc

ponents: FigS1.doc

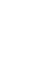

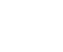

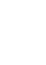

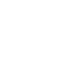

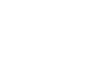

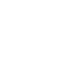
(1) (1) Fonents: Figs1.doc ponents: Figs1.doc . . 西 西 西 西 西 西 西 西 西 西 西 (1)

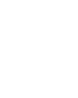

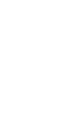

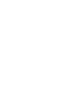

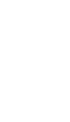

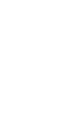

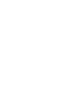

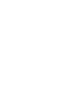

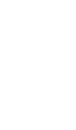

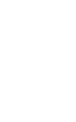
(1) . .

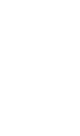

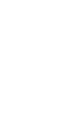

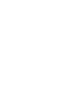

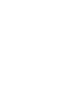

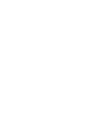
.

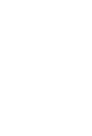

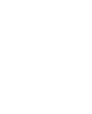

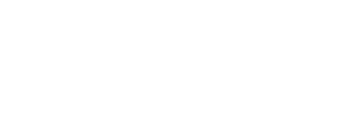

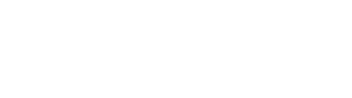

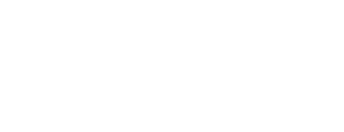

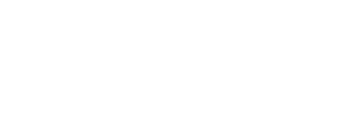
(1) (1)

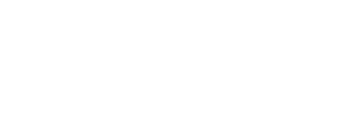

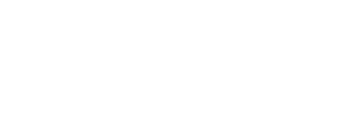

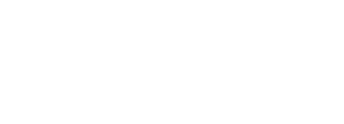

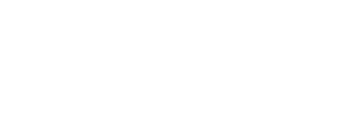

